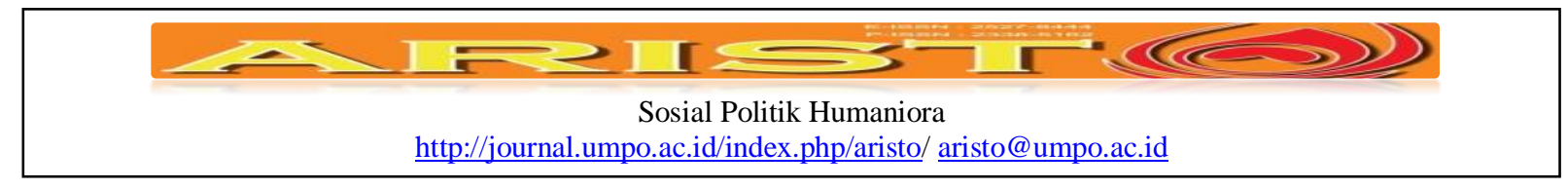

\title{
Kinerja Ombudsman Perwakilan Maluku Utara dalam Mewujudkan Pelayanan Publik yang Prima Di Kota Ternate
}

\author{
Sukur Suleman \\ Ilmu Administrasi Negara, Fakultas Ilmu Sosial dan Ilmu Politik, \\ Universitas Muhammadiyah Maluku Utara \\ sukursuleman@gmail.com
}

\begin{abstract}
This study aims to analyze the performance of North Maluku Representative Ombudsman as a supervisory body in realizing excellent public service in the city of Ternate. This study used a qualitative approach with emphasis on phenomenology. The data obtained from this research is through observation, in-depth interviews and documentation, and secondary data is document tracking. Data analysis technique is qualitative analysis with Milles and Huberman model that is, collecting data, data reduction, display data, conclusion and verification. The results showed that the performance of Ombudsman representative of North Maluku in Ternate City was quite good by looking at the process and stages of acceptance of reports submitted by the community or the Ombudsman's initiative, clarifying the report, field infestigation to convince the existing information, performing mediation actions against the complainant and reported, as well as on the stages of recommendations based on the mechanisms and or rules contained in Law No. 37 of 2008 on the Ombudsman of the Republic of Indonesia. North Maluku Ombudsman is also always working with related institutions and socialize about the functions, duties and authority of Ombudsman, and coordination in order to prevent maladministration practices so that the community can contribute actively and can support the existence of Ombudsman as an independent oversight institution to public service providers both government and private in Ternate City
\end{abstract}

Keyword: Performance, Ombudsman, Public Service.

\begin{abstract}
Abstrak
Penelitian ini bertujuan menganalisis kinerja Ombudsman Perwakilan Maluku Utara sebagai lembaga pengawasan dalam mewujudkan pelayanan publik yang prima di Kota Ternate. Penelitian ini menggunakan pendekatan kualitatif dengan penekanan pada fenomenologi. Data yang diperoleh dari penelitian ini adalah melalui observasi, wawancara mendalam dan dokumentasi, serta data sekunder yakni penelusuran dokumen. Teknik analisis data yaitu analisis kualitatif dengan model Milles dan Huberman yakni, mengumpulkan data, reduksi data, data display, penarikan kesimpulan dan verifikasi. Hasil penelitian menunjukkan bahwa kinerja Ombudsman perwakilan Maluku Utara (OPMU) di Kota Ternate cukup baik dengan melihat pada proses dan tahapan penerimaan laporan yang di sampaikan masyarakat atau insiatif Ombudsman, melakukan klarifikasi terhadap laporan, infestigasi lapangan untuk meyakinkan informasi yang ada, melakukan tindakan mediasi terhadap pelapor dan terlapor, serta pada tahapan rekomendasi yang berdasarkan mekanisme dan atau aturan yang ada dalam UU No 37 tahun 2008 tentang Ombudsman RI. Ombudsman Maluku Utara juga senantiasa kerja sama dengan lembaga-lembaga terkait dan melakukan sosialisasi tentang fungsi, tugas, dan wewenang Ombudsman serta koordinasi dalam rangka mencega terjadinya praktek maladministrasi, sehingga masyarakat dapat berkontribusi aktif dan dapat mendukung eksistensi Ombudsman sebagai lembaga independen pengawasan terhadap penyelenggara pelayanan publik baik pemerintah maupun swasta di Kota Ternate.

Kata Kunci : Kinerja, Ombudsman, Pelayanan Publik
\end{abstract}




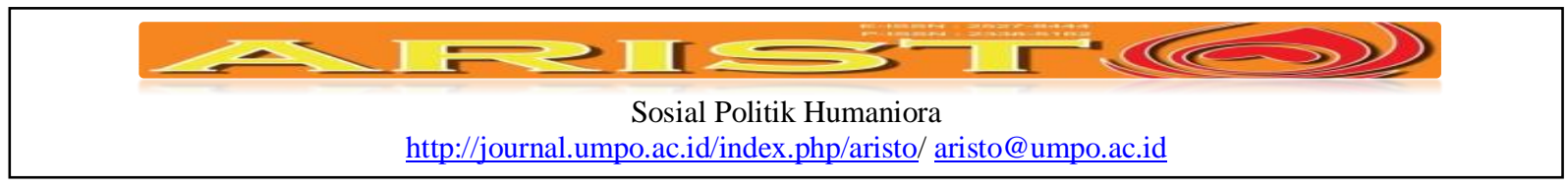

\begin{tabular}{|ll|}
\hline Submite & $:$ 20 November 2017 \\
Review & $:$ 20 Januari 2018 \\
Accepted & $:$ 30 Juni 2018 \\
Surel Corespondensi & $:$ arifzainudin@gmail.com \\
\hline
\end{tabular}

\section{Pendahuluan}

Penyelenggaraan pemerintahan yang bersih dan efektif merupakan dambaan setiap warga Negara. Hal tersebut telah menjadi tuntutan masyarakat yang selama ini hak-hak sipil mereka kurang memperoleh perhatian dan pengakuan secara layak, sekalipun hidup di dalam Negara hukum Republik Indonesia. Sebelum reformasi penyelenggaraan Negara dan pemerintahan diwarnai dengan praktek maladministrasi, antara lain terjadinya korupsi, kolusi, nepotisme, sehingga mutlak di perlukan reformasi birokrasi penyelenggaraan Negara dan pemerintahan, demi terwujudnya penyelenggaraan Negara dan pemerintahan yang efektif dan efisien, jujur, bersih, terbuka, serta bebas dari korupsi, kolusi, dan nepotisme $(\mathrm{KKN})$. Penyelenggaraan Negara dan pemerintahan yang baik hanya dapat tercapai dengan peningkatan mutu aparatur penyelenggara Negara dan pemerintahan, juga penegakan asas-asas pemerintahan umum yang baik (good governance).

Good governance merupakan prasyarat utama untuk mewujudkan aspirasi masyarakat dalam mencapai tujuan dan cita-cita bangsa dan Negara. Dalam rangka hal tersebut, diperlukan pengembangan dan penerapan sistem pertanggungjawaban yang tepat, jelas dan nyata sehingga dalam penyelenggaraan pemerintahan dapat berlangsung secara berdaya guna, berhasil guna bertanggung jawab serta bebas KKN (Uar, 2016). Setelah reformasi bergulir, reformasi mengamanatkan perubahan kehidupan bernegara, berbangsa, dan bermasyarakat, yaitu kehidupan yang didasarkan pada penyelenggaraan Negara dan pemerintahan yang demokratis.

Sejalan dengan semangat reformasi itu, pemerintah melakukan perubahan-perubahan mendasar dalam sistem ketatanegaraan dan sistem pemerintahan Republik Indonesia. Perubahan yang di maksud antara lain dengan membentuk lembaga-lembaga Negara dan lembaga-lembaga pemerintahan yang baru. Salah satu di antaranya adalah lembaga Ombudsman Repblik Indonesia (ORI). Tujuan dibentuknya lembaga ini yaitu dengan visi "Mewujudkan pelayanan publik yang prima yang mensejahterakan dan berkeadilan seluruh rakyat Indonesia“. Tujuan mulia ini tentunya memerlukan proses panjang untuk mewujudkannya, mengingat pelayanan publik 


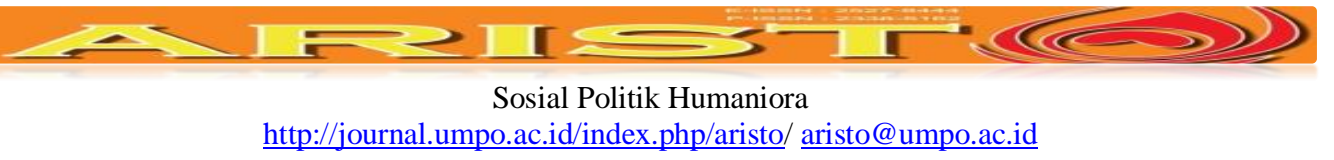

kondisi saat ini secara umum masih rendah kualitasnya, masih banyak masalah yang mengakibatkan terjadinya ketidakpuasan pelayanan publik di masyarakat secara luas.

Di Indonesia penyelenggaraan pelayanan publik menjadi isu kebijakan yang semakin strategis karena perbaikan pelayanan publik di negara ini cenderung berjalan di tempat, sedangkan implikasinya sebagaimana diketahui sangat luas karena menyentuh seluruh ruangruang kepublikan baik dalam kehidupan ekonomi, sosial, politik,budaya dan lain-lain (Mahsyar, 2011).

Sejalan dengan pendapat di atas maka kinerja secara kelembagaan sangat perlu ditingkatakan. Pada dasarnya kinerja merupakan suatu proses yang dilaksanakan secara sinergi antara lembaga, individu dan kelompok terhadap suatu pekerjaan di dalam organisasi. Kinerja didasarkan pada kesepakatan tentang sasaran, rencana kerja dan pengembangan yang mencakup pengkajian ulang terhadap kinerja secara berkesinambungan dan dilakukan secara bersama berdasarkan kesepakatan mengenai sasaran pengetahuan, keahlian, serta pengimplementasian peningkatan dan pengembangan lebih lanjut sebagaimana Dharma (2013) yang mengatakan bahwa kinerja ditunjukkan untuk meningkatkan aspek-aspek kinerja yang meliputi : Sasaran yang akan dicapai, kompetensi yang akan meliputi pengetahuan, keterampilan, sikap, dan efektivitas kinerja.

Ombudsman Perwakilan Maluku Utara adalah merupakan sebuah lembaga pengawasan eksternal yang memiliki fungsi kerja yakni (1) mengakomodasi partisipasi masyarakat dalam upaya memperoleh pelayanan umum yang berkualitas dan efisien, penyelesaian masalah secara adil, tidak memihak dan jujur; (2) meningkatkan perlindungan perorangan dalam memperoleh pelayanan publik, keadilan, kesejahteraan dalam mempertahankan hak-haknya terhadap kejanggalan tindakan penyalahgunaan wewenang (abuse of power), keterlambatan yang berlarutlarut (undue delay), diskresi yang tidak layak. Selanjutnya kinerja Ombudsman Perwakilan Maluku Utara meliputi: Menerima laporan atas dugaan maladministrasi dalam penyelenggaraan pelayanan publik, Melakukan pemeriksaan substansi atas laporan, Menindaklanjuti laporan yang tercakup dalam ruang lingkup kewenangan ombudsman, Melakukan infestigasi atas prakarsa sendiri terhadap dugaan maladministrasi dalam penyelengaraan pelayanan publik, Melakukan koordinasi dan kerja sama dengan lembaga negara atau lembaga pemerintahan lainnya serta lembaga kemasyarakatan dan perseorangan, Membangun jaringan kerja, Melakukan upaya pencegahan maladministrasi dalam penyelenggaraan pelayanan publik, dan Melakukan tugas 


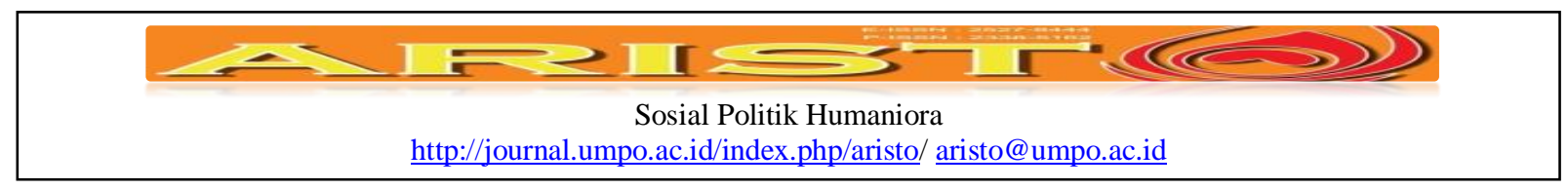

lain yang diberikan oleh undang-undang. Menindaklanjuti pengaduan tersebut dan memberikan rekomendasi untuk perbaikan, serta meningkatkan kualitas pelayanan kepada publik. Menurut Patarai tugas pokok utama Ombudsman adalah mengangkat perilaku buruk pemerintah atau pejabat pemerintah sehingga menjadi perhatian publik agar mendorong suatu perubahan. Dengan demikian dapat di katakan bahwa Ombudsman adalah salah satu aktor sentral dalam penegakan tata kelola pemerintahan yang baik (good governance), penyelenggaraan mekanisme voice, dan partisipasi masyarakat dalam penyelenggaraan pelayanan publik di Kota Ternate. (Patarai. 2010)

Keberadaan lembaga Ombudsman di Maluku Utara menjadi harapan baru bagi seluruh masyarakat Maluku Utara khususnya Kota Ternate, dalam pelaksanaan pemerintahan yang bersih dan bertanggung jawab. Kehadiran Ombudsman di Maluku Utara, masyarakat berharap mendapatkan hak-hak minimumnya dan dapat merasakan pelayanan yang berkualitas dan berkeadialan. Menurut Pramusinto pelayanan publik sudah saatnya diberikan pada masyarakat untuk memenuhi nilai-nilai tentang demokrasi, keadilan, dan transparansi, akuntabilitas yang mencerminkan keinginan masyarakat untuk dapat dilayani secara cepat, profesional, dan mudah diakses di mana pun berada. (Pramusinto.2009)

Dwiyanto menjelaskan bahwa aparatur birokrasi harus bertindak sebagai pelayanan publik yang profesional, santun dan peduli, memiliki integritas tinggi dan mampu menjadi pilar kesatuan bangsa. Menyimak pada pendapat tersebut di atas, maka tentunya pemerintah punya tanggung jawab besar terhadap masyarakat dalam memberikan pelayanan publik yang baik. Oleh karena itu menurut peneliti, salah satu tugas utama pemerintah birokrasi Kota Ternate adalah memberikan pelayanan kepada masyarakat yang sepuasnya penuh dengan keadilan, transparansi dan akuntabilitas. (Dwiyanto. 2015)

Beberapa temuan dari berbagai sumber baik melalui data sekunder Ombudsman, maupun Observasi peneliti diantara Dugaan maladministrasi yang dilakukan oleh Dinas Pendidikan, Kebudayaan, Pemuda dan Olahraga (DIKBUDPORA) terkait tidak diberikannya tunjangan profesi guru dari tahun 2015 hingga awal tahun 2016 serta tidak adanya penyaluran dana rutin sekolah tingkat SD, Dugaan maladministrasi yang dilakukan pihak Jasa Raharja Ternate terkait pembayaran klaim garansi Asuransi yang tidak sesuai dengan jumlah yang diklaim, Keluhan warga kelurahan Tanah Masjid Kota Ternate Tengah atas sering macetnya air dan dinilai PDAM tidak merata dalam pendistribusian air bersih dan, Keluhan masyarakat atas prosedur atau penambahan tarif daya yang dilakukan PLN Cabang Ternate. Kasus-kasus pelayanan publik 


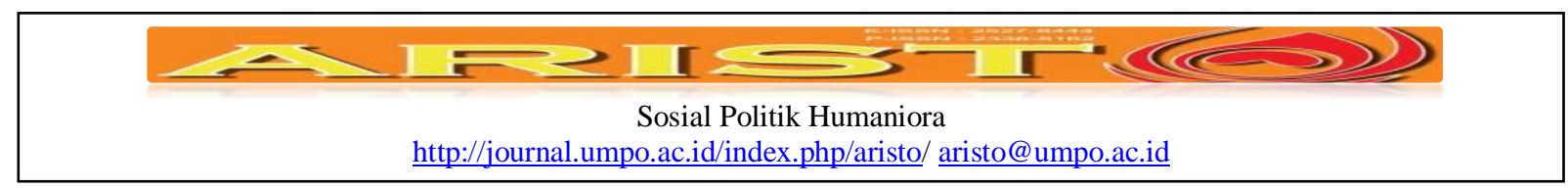

yang lain baik disektor pemerintah seperti dalam pelayanan kesehatan, standar operasional prosedural yang berbelit-belit, layanan administrasi kependudukan yang juga demikian, Begitu pula pada BUMD dan kasus-kasus pada sektor Swata lainnya. Namun Ombudsman perwakilan Maluku Utara sebagai lembaga independen pengawasan pelayanan publik dengan segala tugas, fungsi dan wewenangnya dapat memberikan saran perbaikan kepada penyelenggaraan layanan publik yang melakukan maladministrasi untuk dapat memperbaikinya. Dengan demikian peneliti dapat menyatakan bahwa problem pelayanan publik Kota Ternate dewasa ini perlu melakukan perbaikan dari Ombudsman sesuai dengan harapan masyarakat Kota Ternate.

Pernyataan tersebut di atas dapat diperkuat dengan melihat pada laporan masyarakat maupun temuan Ombudsman Maluku Utara khususnya pada wilayah Kota Ternate mulai Tahun 2014 sebanyak 30 (tiga puluh) aduan terhadap SKPD maupun pihak swasta yang melakukan pelanggaran maladministrasi, di Tahun 2015 laporan yang masuk pada Ombudsman baik pemerintah maupun swasta sebanyak 46 (empat puluh enam) laporan dan terahir Januari-Juni 2016 sebanyak 35 (tiga puluh lima) laporan. Sementara laporan yang masuk dalam kewenangan Ombudsman mulai pada tahun 2014-2016 sebanyak 110 (seratus sepuluh) laporan, dan semuanya menjadi tanggung jawab Ombudsman untuk dapat ditangani dan diselesaikan. Selain itu dalam kinerjanya ada kendala yang dihadapi Ombudsman Maluku Utara itu sendiri, baik sumber daya manusianya, sarana dan prasarana, ketersediaan anggaran, dan pengetahuan masyarakat yang belum mengetahui keberadaan Ombudsman.

Ombudsman perwakilan Maluku Utara yang keberadaannya begitu muda dengan berbagai problem yang dialami, baik secara internal maupun eksternal kelembagaan dan dengan segala tugas dan wewenangnya, serta kendala dan permasalahannya yang dihadapi, tentunya mengisyaratkan bahwa kinerja Ombudsman perwakilan Maluku Utara sebagai lembaga pengawas dalam mewujudkan pelayanan publik yang prima di Kota Ternate perlu ditingkatkan.

Untuk menjawab problem yang dialami Ombudsman baik secara internal maupun eksternal kelembagaan dan dengan segala tugas dan wewenangnya, maka tentunya kinerja Ombudsman harus memiliki indikator yang dapat dijadikan sebagai ukuran keberhasilan dalam menjalankan tugasnya, menurut Danim untuk mencapai hasil yang baik maka mereka harus mampu tampil prima dengan kinerja yang sangat tinggi yaitu memiliki spesifik yang jelas, sehingga dapat dipahami dan tidak ada kemungkinan kesalahan interpretasi, Dapat diukur secara objektif baik yang bersifat kuantitatif maupun kualitatif, Relevan, artinya bahwa kinerja harus menangani 


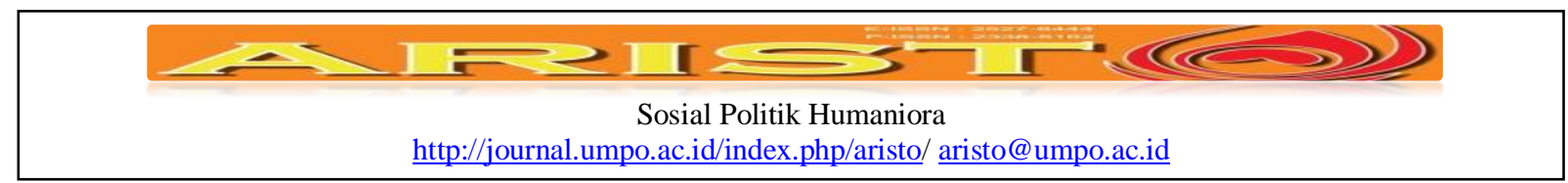

aspek objektif yang relevan, Harus cukup fleksibel dan sensitif terhadap perubahan atau penyesuaian pelaksanaan dan hasil pelaksanaan kegiatan, Efektif data atau informasi yang berkaitan dengan kinerja yang bersangkutan dapat dikumpulkan, diolah dan dianalisis dengan biaya yang tersedia. Hal ini penting dilakukan oleh ombudsman karena akan meningkatkan partisipasi publik dalam pengaduan terhadap maladministrasi atau kasus pelayanan publik dan tentunya akan lebih mempermudah Ombudsman perwakilan Maluku Utara dalam mewujudkan pelayanan publik yang prima di Kota Ternate. (Danim. 2008),

\section{Metode}

Penelitian ini dilakukan di Kota Ternate Provinsi Maluku Utara selama 2 (dua) bulan dengan pertimbangan bahwa fenomena aparatur penyelenggara pelayanan publik di Kota Ternate Propinsi Maluku Utara diwarnai dengan kondisi birokrasi yang kurang sesuai dengan landasan normatif dan prinsip-prinsip ilmiah, yang membuat pelayanan publik tidak efisien. Sehingga menuntut kinerja Ombudsman Perwakilan Maluku Utara sebagai lembaga pengawasan pelayanan publik untuk lebih mendorong terwujudnya pelayanan publik yang prima di Kota Ternate. Penelitian ini menggunakan deskriptif kualitatif dengan melihat bahwa kinerja Ombudsman dalam mewujudkan pelayanan publik yang prima di Kota Ternate memuat problem sosial yang membutuhkan pemahaman secara universal agar dapat memperoleh data secara akurat. Oleh karena itu penelitian ini mengacu pada penelitian kualitatif, maka berdasarkan fenomena yang ada, pendekatan penelitian ini adalah fenomenalogi yaitu berdiskusi tentang suatu objek kajian dengan memahami inti pengalaman dari suatu fenomena. Peneliti akan mengkaji secara mendalam isu sentral dari struktur utama suatu objek kajian dan selalu bertanya apa pengalaman utama yang akan dijeleskan informan tentang objek kajian penelitian, serta berusaha memahami arti peristiwa dan kaitan-kaitannya terhadap orang-orang dalam situasisituasi tertentu, maka dengan demikian peneliti menggambarkan pengalaman yang dilakukan dan dialami oleh para informan terhadap kinerja Ombudsman perwakilan Maluku Utara dalam mewujudkan pelayanan publik yang prima di Kota Ternate.

Penelitian ini juga menggunakan sumber data yaitu data primer yang diperoleh melalui observasi, melakukan wawancara mendalam, dan dokumentasi. Peneliti memilih informan berdasarakan teknik Purposive yaitu memili informan berdasarkan kriteria tertentu yang telah ditetapkan yang sesuai dengan topik penelitian, mereka yang dianggap cakap, kredibel untuk 


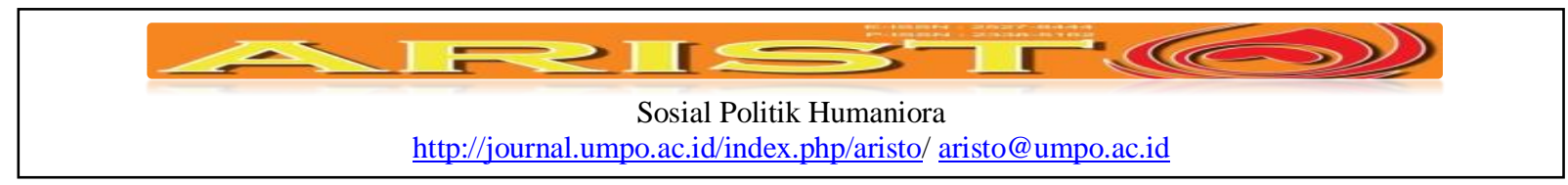

menjawab masalah penelitian. Dan yang menjadi informan dalam penelitian ini yaitu Komisioner Ombudsman, Asisten dan Staf, masyarakat pelapor, tokoh masyarakat atau LSM dan Pemerintah Kota Ternate yang terlapor. Kemudian sumber data selanjutnya adalah data sekunder berupa data-data yang didapat dari sumber bacaan dan berbagai macam sumber lainnya, baik berupa penelusuran dokumen laporan-laporan tertulis dan peraturan-peraturan lainnya. Kedua sumber tersebut dapat diuji kredibilitasnya dan dapat dianalisis dengan menggunakan model interaktif teknik analisis data oleh Miles and Huberman yaitu data Collection, data Display, data Reduction, Conclution Drawing/Verifyingi. (Sugiyono, 2014)

\section{Hasil dan Pembahasan}

Dalam rangka menjalankan kinerjnnya sebagai lembaga pengawasan pelayanan publik, maka peneliti mengacu pada tiga indikator untuk mengukur kinerja organisasi publik oleh Dwiyanto (2006) yaitu produktivitas kinerja, responsivitas dan responsibilitas yang dapat digambarkan berdasarkan hasil penelitian diantaranya:

\section{Produktivitas Ombudsman dalam menjalankan fungsi pengawasan.}

Produktivitas menunjukkan pada dua dimensi yaitu efektivitas dan efisiensi dengan pandangan bahwa kinerja yang dilakukan hari ini itu lebih baik dari pada kinerja yang selalu ditunda-tunda, dimana pada efektivitas yaitu melaksanakan sesuatu yang benar dalam memenuhi kebutuhan organisasi berkaitan dengan pencapaian untuk kinerja yang maksimal. Sementara pada efisiensi berkaitan dengan upaya membandingkan masukan dengan realisasi bagaimana kinerja tersebut dapat dilaksanakan. Sebagai upaya Ombudsman perwakilan Maluku Utara untuk meningkatkan kepercayaan masyarakat terhadap produktivitas kinerja Ombudsman dalam menjalankan fungsi pengawasannya maka, pendekatan yang perlu dipakai adalah pendekatan Simamora (2004) yang mengatakan keberhasilan produktivitas kerja sangat berpengaruh pada kuantitas kerja, kualitas kerja dan ketetapan waktu oleh karena itu untuk melihat kuantitas, kualitas dan ketetapan waktu kinerja sebuah organisai publik terutama kinerja Ombudsman perwakilan Maluku Utara maka, sejauh peneliti melakukan penelitian dan dengan hasil kajian dan observasi yang ada, untuk itu peneliti dapat menguraikan beberapa bahasan dengan melihat pada sub indikator dibawah ini:

Kuantitas kinerja berkaitan dengan suatu hasil yang dicapai oleh Ombudsman berdasarkan standar dan mekanisme kerja sesuai dengan tugas yang dimilikinya. Oleh karena 


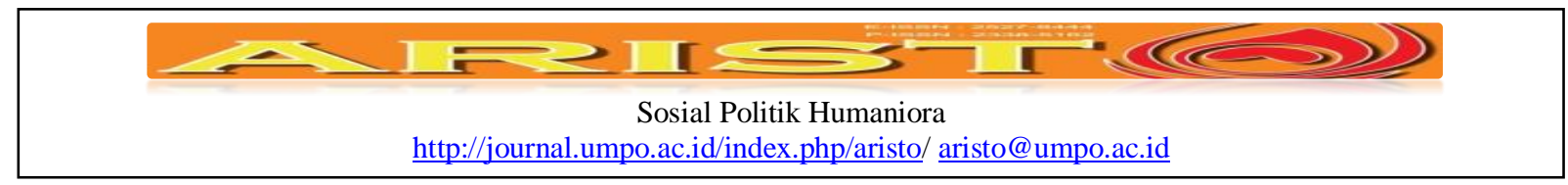

itu, peneliti mendeskripsikan hasil penelitian terkait dengan kinerja Ombudsman perwakilan Maluku Utara dalam mewujudkan pelayanan publik yang ada di Kota Ternate, berdasarkan tugas Ombudsman yang di atur dalam Undang-Undang Nomor 37 Tahun 2008 diantaranya:

Hasil observasi peneliti dan telaah dokumen menunjukkan bahwa kinerja Ombudsman diawali dengan penerimaan laporan yaitu sejak 2015 dan Januari-Juni 2016 dari 81 kasus yang ditangani oleh Ombudsman Perwakilan Maluku Utara sebanyak 23 hasil temuan atau inisiatif sendiri sementara 34 berasal dari laporan langsung dan 24 adalah laporan melalui via email, surat, telepon maka dengan demikian peneliti berkesimpulan bahwa inisiatif Ombudsman itu sangat penting walaupun dengan capaian yang minimal tetapi sangat berpengaruh terhadap efektivitas dan efisiensi kinerja Ombudsman dalam menjalankan fungsi pengawasannya. Adapun gambaran data mengenai jumlah kasus aduan atau laporan berdasarkan instansi pemerintah maupun swasta dalam lingkup Kota Ternate, dapat digambarkan pada tabel 1.1 berikut ini:

Tabel 1 : Laporan Kasus Ombudsman Perwakilan Maluku Utara 2015-2016.

\begin{tabular}{|c|c|c|}
\hline No & Instansi Terlapor & Jumlah Kasus \\
\hline $\begin{array}{l}1 . \\
2 . \\
3 . \\
4 . \\
5 . \\
6 . \\
7 . \\
8 . \\
9 . \\
10 . \\
11 . \\
12 . \\
13 . \\
14 . \\
15 . \\
16 . \\
17 . \\
18 . \\
19 . \\
20 . \\
21 . \\
22 . \\
23 . \\
24 . \\
25 . \\
26 . \\
27 . \\
28 . \\
29 . \\
30 .\end{array}$ & $\begin{array}{l}\text { Disnakersos } \\
\text { Dinas Pendidikan } \\
\text { Dinas Tata Kota dan Pertamanan } \\
\text { BLHK } \\
\text { Dinas Perhubungan } \\
\text { Badan Perlindungan Perempuan dan Anak } \\
\text { BRI } \\
\text { Kelurahan } \\
\text { Dinas Pasar } \\
\text { Dinas Kesehatan } \\
\text { RSUD } \\
\text { Telkom } \\
\text { Badan Pusat Statistik (BPS) } \\
\text { Kecamatan } \\
\text { Sekolah } \\
\text { PT. Danamon } \\
\text { Dinas Kebersihan } \\
\text { Kepolisian } \\
\text { ASDP } \\
\text { Kantor Pelayanan Pajak Pratama } \\
\text { Pertamina } \\
\text { BPN } \\
\text { Pengadilan Negeri } \\
\text { Pengadilan Agama } \\
\text { Dinas Catatan Sipil dan Kependudukan } \\
\text { Dinas Kebudayaan dan Parawisata } \\
\text { Jasa Raharja } \\
\text { PLN } \\
\text { PDAM } \\
\text { Perguruan Tinggi }\end{array}$ & $\begin{array}{l}3 \\
3 \\
1 \\
2 \\
4 \\
1 \\
2 \\
4 \\
4 \\
2 \\
2 \\
1 \\
1 \\
1 \\
15 \\
1 \\
1 \\
2 \\
1 \\
2 \\
2 \\
3 \\
1 \\
1 \\
2 \\
1 \\
1 \\
8 \\
4 \\
5\end{array}$ \\
\hline & Total Jumlah Kasus & 81 \\
\hline
\end{tabular}

Sumber : (Data sekunder OMPU, 2016) 


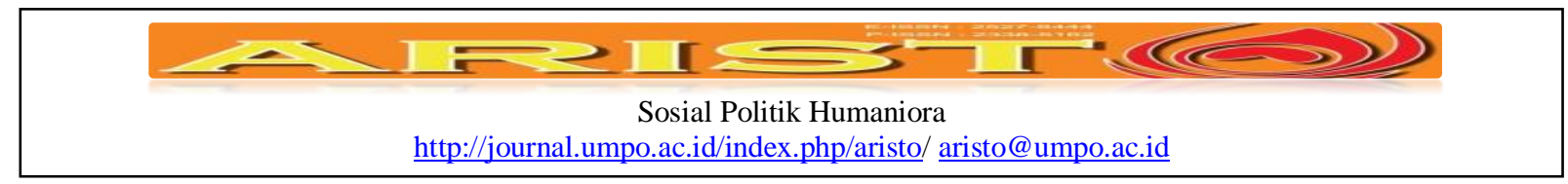

Hasil observasi dan telaah dokumen juga menunjukkan bahwa dari seluruh jumlah instansi terlapor yang ditangani Ombudsman baik dari sektor pemerintah maupun swasta yang paling dominan melakukan pelanggaran pelayanan publik atau maladministrasi adalah instansi pendidikan atau sekolah dengan jenis kasus yang sangat seragam yakni masalah pungutan liar (pungli), iuran kepada siswa yang penggunaannya tidak jelas, hal ini memungkinkan dampak dari pada kebijakan pendidikan gratis yang pada aspek lain pihak sekolah merasah kewalahan, sementara yang sering berulang kali melakukan kesalahan adalah PLN dengan jenis kasus yang juga seragam yakni pemadaman listrik yang berlarut larut, listrik yang sering mati dan sebagainya. Begitu juga dengan lembaga-lembaga lainnya yang melakukan pelanggaran berulang kali tetapi tidak seperti yang terlihat pada angka yang dominan, kondisi ini memungkinkan peran serta pengaruh pemimpin yang yang kurang efektif dalam dalam mengorganisir sebuah lembaga atau instansi.

Pernyaatan ini didukung oleh Terry yang mengatakan bahwa kepemimpinan adalah aktivitas untuk mempengaruhi orang-orang supaya diarahkan untuk mencapai tujuan organisasi, kepemimpinan meliputi proses mempengaruhi dalam menentukan tujuan organisasi, memotivasi prilaku pengikut untuk mencapai tujuan serta mempengaruhi untuk memperbaiki kelompok dan budaya organisasi. Maka dengan demikian peneliti berkesimpulan bahwa pelanggaran yang berulang kali dilakukan oleh instansi terlapaor menandakan manajemen kepemimpinan dari instansi yang belum maksimal dan sikap Ombudsman yang harus lebih tegas. (Thoha 2010)

Kualitas kerja Ombudsman terhadap penanganan laporan masyarakat yang masuk, dapat diselesaikan berdasarkan tugas, fungsi dan wewenang Ombudsman. kinerja Ombudsman dalam penanganan laporan sudah mulai terlihat dan manfaatnya dapat dirasakan oleh masyarakat pelapor.

Tabel II: Jumlah Pengaduan Masyarakat yang Masuk dalam Kewenangan OmbudsmanTahun 2014-2016

$\begin{array}{cccccc}\text { No } & \text { Jenis } & \mathbf{5 0 1 4} & \mathbf{2 0 1 5} & \mathbf{2 0 1 6} & \text { Jumla } \\ \text { 1. Pelayanan } & \text { Pemerintah } & 20 & 29 & 31 & 79 \\ \text { 2. Swasta } & 10 & 17 & 4 & 31 \\ \text { Total Per Tahun } & 30 & 46 & 35 & 110\end{array}$

Sumber: (Data Sekunder OPMU, 2016) 


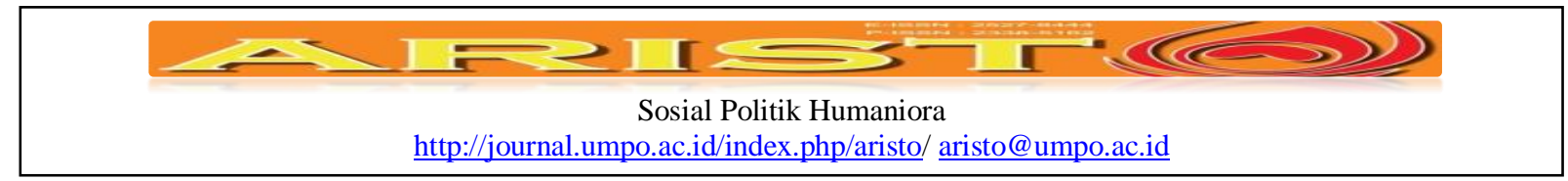

Berdasarkan Tabel II di atas dapat digambarkan bahwa kinerja OPMU dalam penanganan laporan sudah mulai terlihat dan manfaatnya dapat dirasakan oleh masyarakat pelapor, akan tetapi pada tahun 2014 terdapat penurunan laporan sebesar 30 laporan, dengan alasan bahwa diawal-awal berdirinya Ombudsman perwakilan Maluku Utara, bekerja dengan serba keterbatasan personil yang hanya memiliki 2 (dua) Asisten dan pengetahuan masyarakat atas kehadiran Ombudsman yang sangat kurang sehingga, kehadiran Ombudsman diawal tahun bekerja sangat mengalami kekurangan laporan.

\section{Gambar I : Diagram Klasifikasi Laporan / Aduan Berdasarkan Mekanisme Penyampaian Laporan}

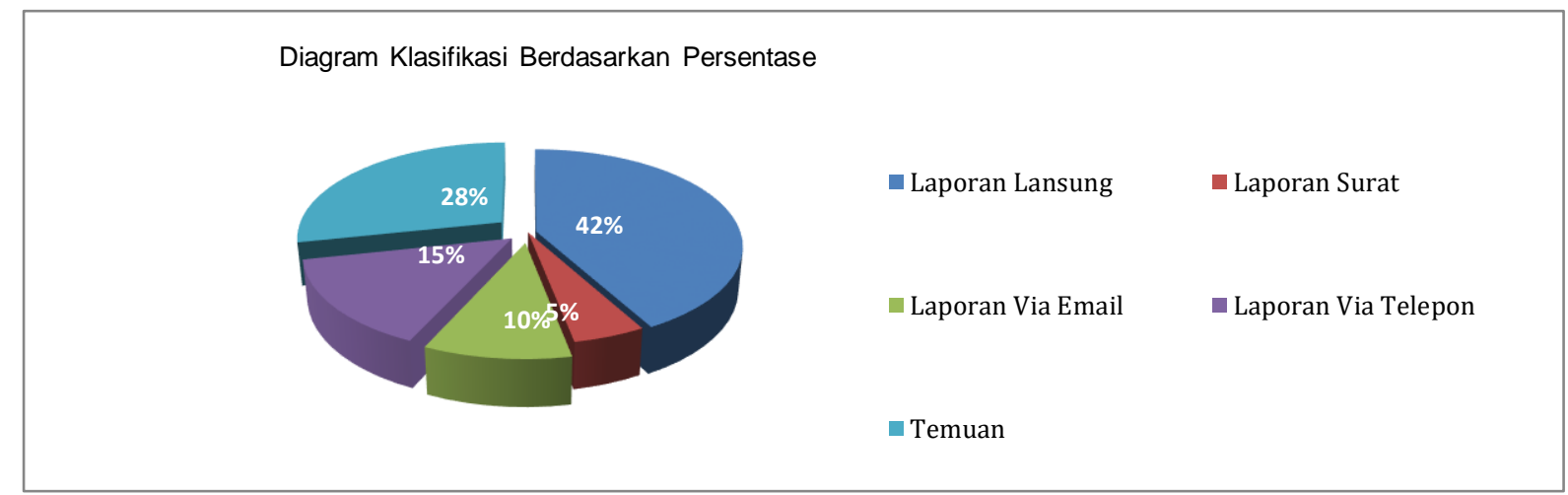

Sumber : Data Sekunder OMU 2016

Hal penting yang juga perlu dikemukakan adalah lembaga sektor publik maupun sektor swasta yang dilaporkan dari jumlah keseluruhan laporan atau aduan serta temuan selama tahun 2015 dan Januari-Juni Tahun 2016 kepada Ombudsman perwakilan Maluku Utara sebagaimana tercantum pada tabel 4.7 dibawah ini:

\section{Tabel III: Jumlah Instansi Terlapor Sektor Pemerintah}

\section{No Instansi Terlapor Jumlah Laporan}

1. Kantor Dinas atau Badan 37

2. Pemerintahan Kecamatan 1

3. Pemerintahan Kelurahan 4

4. Satuan Pendidikan/ Sekolah 15

5. BUMN/BUMN 20

Total 77

Sumber : (Data sekunder OPMU, 2016) 


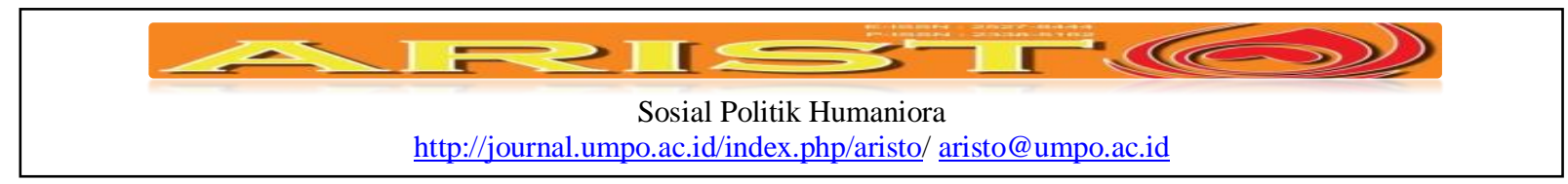

Dari hasil olahan data sekunder OPMU pada tabel tersebut, dapat dilihat bahwa, instansi terlapor dari sektor pemerintah yang paling banyak mendapat laporan adalah kantor dinas dan atau badan yakni dengan jumlah laporan yang masuk pada Ombusman Maluku Utara adalah sebanyak 77 kasus, ini menunjukkan bahwa aduan atau laporan masyarakat untuk dinas atau badan dapat digaris bawahi diantaranya pelayanan yang berbelit-belit dan kaku, kemudian kepentingan masyarakat yang tidak mampu diakomodir, pungutan pembayaran yang diluar dari mekanisme dan prosedur pelayanan. Sedangkan pada Kantor kecamatan dan kelurahan pada umumnya juga pelayanannya berlarut-larut dan melalaikan kewajibannya serta bertindak diluar kewenangan yang ada. Pada pendidikan atau sekolah antara lain adalah pungutan atau biaya partisipasi yang penggunanya tidak jelas, serta penjualan buku kepada siswa.

Selanjutnya jumlah instansi yang terlapor pada sektor Swasta sebagaimana pada tabel berikut ini:

Tabel IV: Jumlah Instansi Terlapor Sektor Swasta

\section{No Bidang Terlapor Jumlah Laporan}

1. Kontraktor 0

2. Asuransi dan Pembiayaan 1

3. Perdagangan barang dan Jasa 0

4. Perbankan dan keuangan 3

5. Pribadi 0

Total 4

Sumber : (Data Sekunder OPMU, 2016)

Pada tabel IV tersebut dapat menjelaskan bahwa jumlah aduan atau laporan terhadap sektor swasta yang masuk pada Ombudsman itu sangat menurun, dimana jumlah laporan terbanyak hanyalah 3 kasus yaitu perbankan dan keuangan dengan jenis kasus yang dilaporakan oleh masyarakat adalah pemutusan pinjaman pelapor sebelum berahirnya perjanjian pinjaman yang mengakibatkan sertifikat pelapor yang dijaminkan disita oleh pihak Bank Danamon, pihak Bank BRI tidak mau memberikan sertifikat milik pelapor yang dijaminkan pada saat pinjaman uang di Bank padahal pelapor sudah melunasi pinjaman tersebut. Minimnya laporan terhadap sektor swasta dengan asumsi bahwa pihak swasta telah bekerja berdasarkan manajemen profesional. Untuk lebih mempertegas penjelasan diatas tentang kondisi laporan pada sektor swasta. 


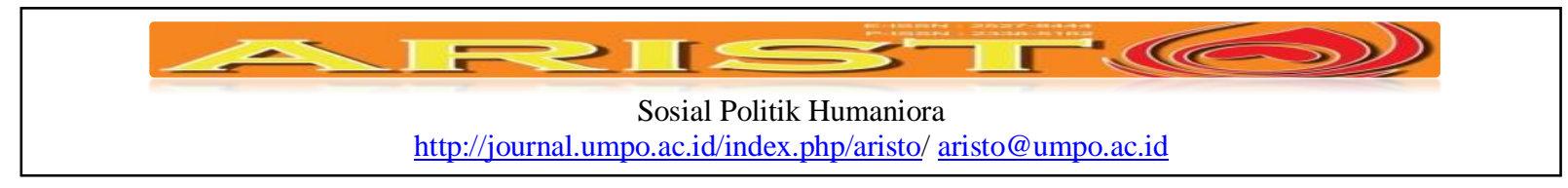

Tabel V: Klasifikasi Laporan atau Aduan Berdasarkan Proses Tindak Lanjut

\section{No Tindak Lanjut Laporan \\ Jumlah Laporan}

1. Kasus selesai atau tutup (yaitu selesai dengan investigasi, mediasi, dan penghentian tindak lanjut)

2. Rekomendasi

3. Dalam Proses

4. Tahapan Konsultasi

5. Tidak ditindak Lanjuti

Sumber : (Data sekunder OPMU, 2016)

Pada tabel V tersebut dapat dilihat bahwa klasifikasi laporan berdasarkan proses tindak lanjut menunjukkan jumlah kasus yang diselesaikan dengan investigasi, mediasi, dan penghentian tindak lanjut sebanyak 68 laporan. Dengan alasan kasus selesai dikarenakan proses tindaklanjuti laporan terhadap instansi yang terlapor Ombudsman lebih memberikan saran perbaikan kepda pihak terlapor dan mereka langasung melaksanakan, sementara pada tahap proses penyelesaian kasus, saat ini sedang berlansung karena Ombudsman butuh kajian mendalam dan pengutan data-data yang valid, begitu juga tahapan konsultasi yang tentunya saling mencocokkan antara data dari pihak terlapor dengan dengan jenis kasus yang dilaporkan. Sementara untuk tahapan rekomendasi dan kasus yang tidak ditindaklanjuti oleh Ombudsman perwakilan Maluku Utara itu tidak ada. Melalui data tersebut dapat diambil suatu kesimpulan bahwa kinerja OPMU dalam menangani permasalahan yang dilaporkan masyarakat mulai 2015 -2016 tergolong cukup tinggi.

Untuk melihat persentase laporan berdasarkan tindak lanjut penyelesaian laporan dapat dilihat pada gambar 4.4 berikut: 


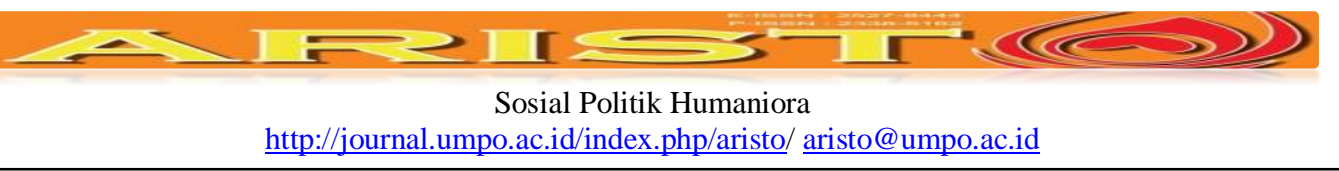

Gambar II : Diagram Klasifikasi Laporan Berdasarkan Proses Tindak Lanjut

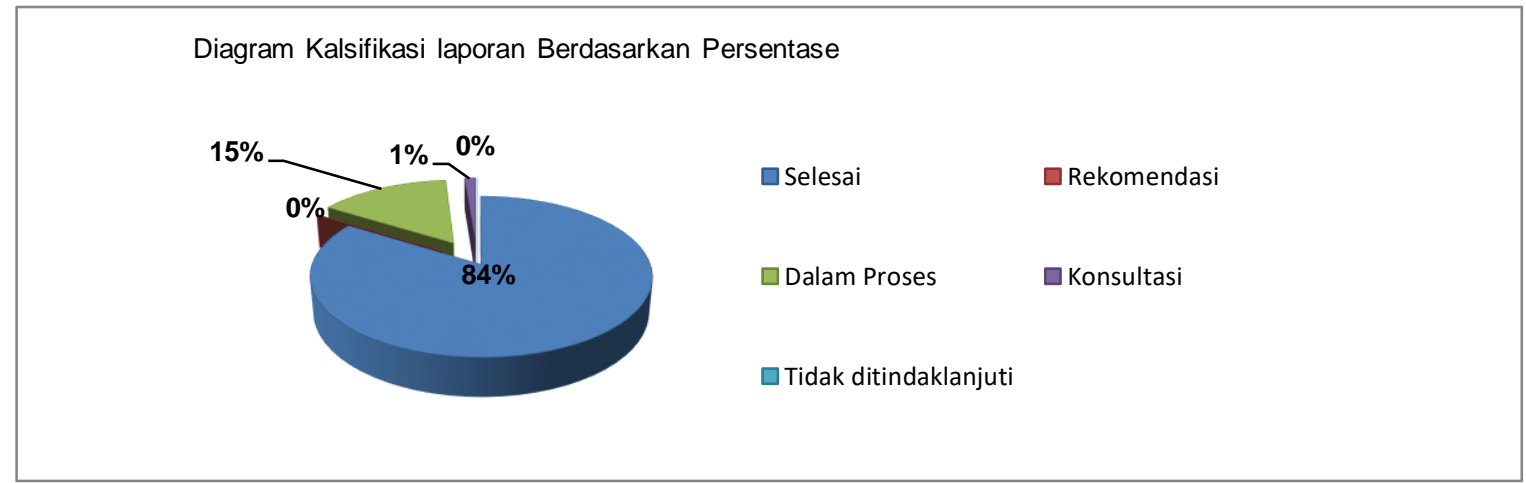

Sumber : (Hasil olahan data sekunder OPMU, 2016)

Maka dengan demikian produktivitas Ombudsman dalam menjalankan fungsi pengawasan berdasarkan tugas Ombudsman yang diatur dalam undang-undang No 37 Tahun 2008 yakni di mulai dari Proses dan tahapan penerimaan laporan, proses klarivikasi, proses investigasi, dan mediasi telah dijalankan oleh Ombudsman perwakilan Maluku Utara khususnya fungsi pengawasan yang dilakukan pada pemerintah Kota Ternate. Hanya saja pada tahapan rekomendasi Ombudsman perwakilan Maluku Utara belum mengeluarkan kepada instansi terlapor terhadap sejumlah kasus yang di dilaporakan oleh masyarakat maupun hasil temuannya sendiri. rekomendasi senantiasa belum dilaksanakan, karena rekomendasi bersifat mengikat dan memiliki sanksi yang tegas terhadap pelaku maladministrasi bahkan pada tingkat pidana, atas dasar itulah instansi terlapor yang ada di Maluku Utara terutama Kota Ternate lebih mempertimbangkan kemudaratannya dan menjalankan saran perbaikan yang diberikan Ombudsman, sehingga sampai saat ini Ombudsman perwakilan Maluku Utara belum mengeluarkan tahapan rekomendasi.

\section{Responsivitas Ombudsman terhadap aduan masyarakat}

Responsivitas menurut Dwiyanto (2006) adalah merupakan kemampuan organisasi untuk mengenali kebutuhan masyarakat, dalam konteks ini responsivitas mengacu pada keselarasan antara program dan kegiatan berdasarkan kebutuhan dan aspirasi masyarakat. Responsivitas menggambarkan kemampuan lembaga dalam menjalankan misi dan tujuannya. Ombudsman perwakilan Maluku Utara sangat merespon dengan baik dan selalu memprioritaskan apa yang menjadi kebutuhan atau tuntutan masyarakat yang merupakan pihak yang merasa dirugikan. 


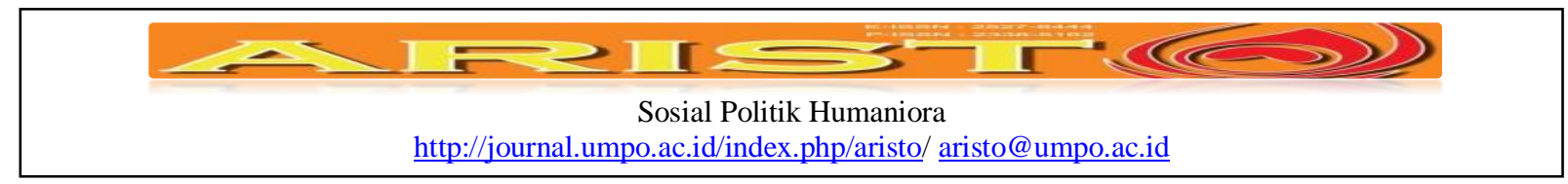

Seiring dengan pembenaran pernyataan tersebut maka dapat diperkuat melalui hasil wawancara dengan RS seorang informan pelapor yang menyatakan bahwa:

"Pada saat saya melaporkan sebuah kasus maladministrasi di Ombudsman, kasus dugaan maladministrasi yang dilakukan oleh pihak Sekolah SMP Negeri 2 Kota Ternate terkait penjualan buku pelajaran, dan ketika saya melaporkan kasus itu ke Ombudsman saya tidak kenakan pungutan biaya atau imbalan apapun itu (Hasil wawancara RS, Juli 2016)”.

Berdasarkan pernyataan dari RS sebagai pihak pelapor, hal ini membuktikan bahwa benar Ombudsman perwakilan Maluku Utara tidak memungut biaya atau imbalan dari masyarakat ketika memasukkan laporannya, hasil temuan peneliti bahwa memang untuk mengenai laporan masyarakat ke Ombudsman itu tidak dikenakan pungutan biaya atau imbalan, dan itu diatur dalam Undang-Undang Ombudsman pasal 23 ayat 2.

Hasil wawancara juga menunjukkan bahwa Ombudsman perwakilan Maluku Utara dalam menerima laporan dari masyarakat tidak sama sekali dikenakan biaya atau imbalan, melaporkan pelanggaran baik itu berupa korupsi, kolusi, nepotisme merupakan hak mutlak bagi setiap warga negara atau masyarakat setempat yang merasa dirugikan sejauh laporan atau aduan masyarakat itu berhubungan dengan maladministrasi, penyalahgunaan wewenang oleh pejabat atau Instansi terkait itu adalah tindakan semena-mena dan perilaku tidak etis sebagai penyelenggara negara, terutama penyelenggara negara dibidang pelayanan publik, maka dengan demikian temuan yang seperti itu wajib hukumnya sebagai masyarakat untuk melaporkan kepada lembaga yang berwenang untuk mengeksekusi atau merekomendasikan sesuai dengan peraturan perundang-undangan yang berlaku, dan Ombudsman sebagai lembaga independen yang mengawasi pelayanan publik sangat merespon dengan baik terhadap aduan masyarakat.

Ombudsman merupakan lembaga pengawasan pelayanan publik, setelah menerima laporan atau aduan dari masyarakat, maka Ombudsman juga melakukan pemeriksaan substansi terhadap laporan yang diterima dari masyarakat, apakah laporan tersebut masuk pada kewenangan Ombudsman, atau tidak termasuk dalam kewenangan Ombudsman, karena sebagian juga masyarakat yang memasukkan laporan yang substansinya bukan dalam kewenangan Ombudsman, sehingga pemeriksaan substansi sangat perlu untuk dilakukan. Dengan segala kewenangan yang dimiliki Ombudsman maka akan mengurangi berbagai praktek mal administrasi terhadap aparatur penyelenggara layanan publik. Ini kemudian 


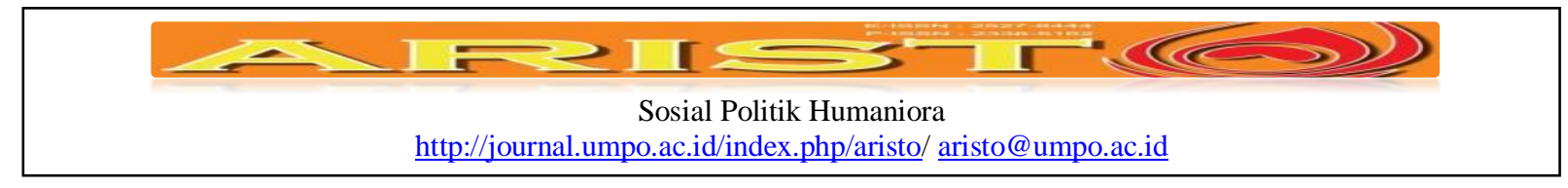

sangat relevan dengan pendapat Syamsudin (2009), bahwa dengan wewenang yang relatif luas, kehadiran lembaga Ombudsman akan mengikis berbagai praktik maladministrasi publik (penyalahgunaan kekuasaan, penyimpangan wewenang atau jabatan) oleh oknum aparatur instansi pelayanan publik, dengan segala wujud dan modusnya, dari dunia pelayanan publik di Indonesia.

Hasil Observasi menunjukkan Ombudsman sebagai lembaga pengawasan pelayanan publik yang memiliki posisi mandiri dan independen, membangun jaringan yang luas kepada seluruh stakeholder guna memperlancar kinerjanya terutama dalam mencari informasi dan data yang akurat terkait dengan pelaksanaan pelayanan yang bersifat maladministratif. Lembaga-lembaga yang dijadikan mitra dengan Ombudsman terdiri dari Lembaga Sosial Masyarakat (LSM), lembaga pemberdayaan masyarakat, tokoh masyarakat, RT/RW, sebab dengan membangun jaringan kepada lembaga tersebut akan memperlancar dan memudahkan koordinasi jika ternyata ada dugaan yang terjadi. Selain itu tentunya juga jaringan harus dibangun dengan instansi-instansi pemerintahan maupun lembaga-lembaga negara independen lainnya yang ada di Maluku Utara khususnya Kota Ternate, selain itu juga Ombudsman juga bekerja sama dengan lembaga perguruan tinggi baik itu negeri maupun swasta. Selanjutnya dalam merespon segala permasalahan yang ada dan untuk perbaikan penyelenggara layanan terhadap pencegahan maladministrasi maka Ombudsman senantiasa melakukan kegiatan antara lain: (a) melakukan sosialisasi tentang fungsi, tugas, dan wewenang Ombudsman, sehingga masyarakat dapat berkontribusi aktif dan dapat mendukung eksistensi Ombudsman sebagai lembaga independen pengawasan terhadap penyelenggara pelayanan publik baik pemerintah maupun swasta. Melakukan diskusi publik, dialog dan seminar terkait eksistensi Ombudsman di Maluku Utara di Kota Ternate, (b) Melakukan sosialisasi tentang prosedur pelayanan publik aparat pemberi layanan kepada penerima layanan, serta swasta sesuai dengan Undang-Undang Nomor 25 Tahun 2009 kepada masyarakat, (c) melalui Focus Group Discusiion (FGD) dengan menghadirkan masyarakat sebagai penerima layanan publik dan pemberi layanan publik selaku penyelenggara pelayanan publik, (d) talk show melalui media, pemasangan iklan layanan publik di media cetak, media online seperti facebook, twitter,WA, dan lain sebagainya. Penjelasan tersebut dapat dibuktikan dengan hasil wawancara yang disampaikan oleh AFA salah seorang asisten yang menyatakan bahwa: 


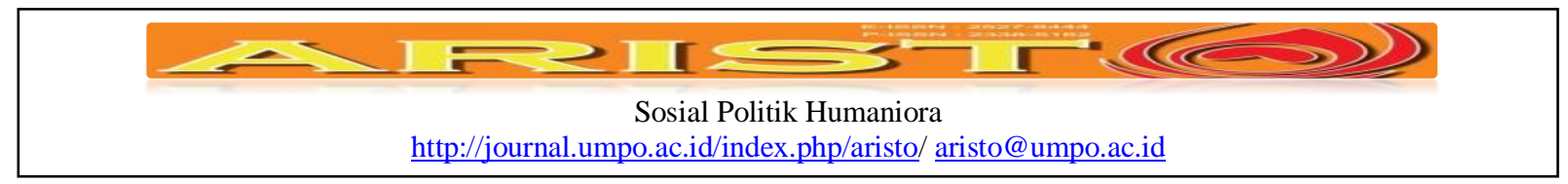

"Memang upaya-upaya yang kami lakukan untuk mencegah terjadinya maladministrasi di Kota Ternate adalah melakukan sosialisasi tentang peran Ombudsman, dialog, diskusi maupun seminar, Focus Group Discusiion (FGD), pemasangan iklan, pemanfaatan media cetak dan online, baliho, spanduk dan penyuluhan kepada instansi terkait (Hasil wawancara AFA,Juni 2016)"

Pencegahan terhadap maladministasi dengan upaya yang dilakukan Ombudsman merupakan langkah yang paling baik untuk mengurangi tingkat pelanggaran yang dilakukan oleh instansi baik dari sektor pemerintah maupun sektor swasta, hal ini menunjukkan bahwa Ombudsman memiliki peran yang sangat penting untuk memberikan kesadaran akan hak-hak masyarakat mendapatkan pelayanan yang sepatutnya, kesadaran tugas dan kewajiban sebaga aparatur penyelenggara Negara dalam memberikan pelayanan publik yang berkualitas, maka dengan demikian wujud dari pada pelayanan publik yang prima itu bisa tercapi dan hasilnya dapat dirasakan oleh masyarakat,apabila masyarakat diutamakan dan merasakan kepuasan, hal ini kemudian diperkuat oleh Nadzaria (2013) yang mengatakan bahwa yang dimaksud dengan pelayanan prima itu adalah masyarakat merasa penting, sebagai mitra, pelayanan yang cepat dan tepat serta mengutamakan pelayanan optimal yang menghasilkan kepuasan pelanggan.

\section{Responsibilitas Ombudsman terhadap penerimaan dan penyelesaian laporan masyarakat.}

Responsibiltas merupakan kemampuan organisasi untuk mengatur sejauhmana pemberian layanan telah berjalan sesui dengan aturan yang diberlakukan atau prosedur yang telah ditentukan berdasarkan prinsip-prinsip atau ketentuan-ketentuan administrasi dan organisasi yang benar telah ditetapkan sebagaimana dikatakan oleh Lenvine dalam (Sembering 2012) bahwa responsibilitas adalah suatu ukuran yang menunjukkan pelaksanaan organisasi publik sesuai dengan prinsip-prinsip administrasi yang benar atau sesui dengan kebijakan organisasi baik yang eksplisit maupun implisit.

Responsibilitas Ombudsman terhadap penyelesaian laporan masyarakat yang dimaksud dalam penelitian kali ini adalah bagaimana kinerja Ombudsman perwakilan Maluku Utara dalam menyelesaikan aduan atau laporan, baik dari masyarakat atau hasil temuan sendiri berdasarkan insiatif, itu kemudian berdasarkan prinsip administrasi atau tidak lepas dari mekanisme dan prosedur yang berlaku secara konstitusi atau Undang-Undang Ombudsman 


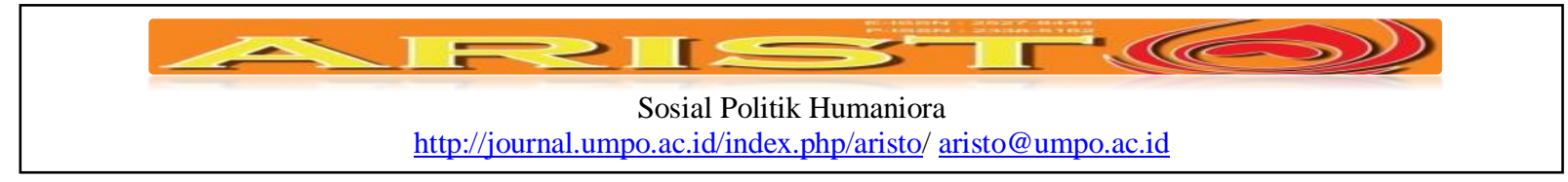

dan dengan kata lain prosedur yang telah disepakati bersama atau biasa disebut dengan Standar Operasional Prosedur (SOP) yang berlaku pada lembaga Ombudsman. Suatu hal yang menjadi penentu atas keberhasilan Ombudsman dalam menjalankan fungsinya adalah sejauh mana kesiapan dan kelengkapan administratif untuk mendukung setiap kegiatan Ombudsman dalam hal penerimaan dan penyelesaian laporan.

Gambar III: Alur Penerimaan dan Penyelesaian Laporan/Pengaduan

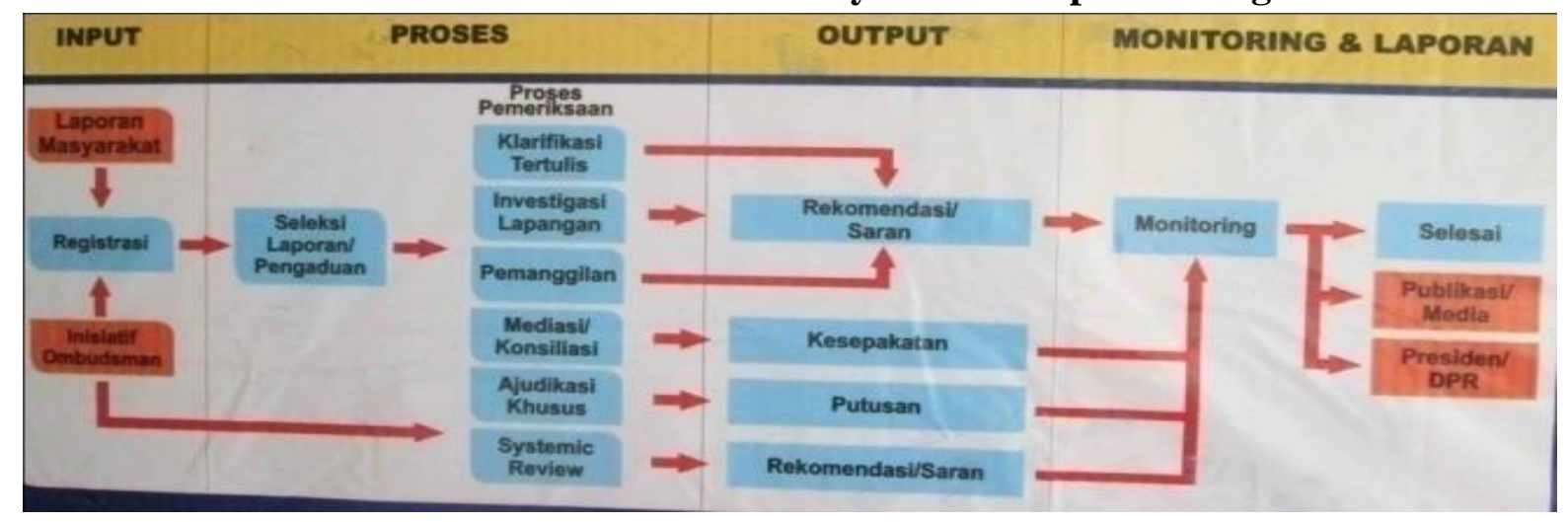

Sumber : (Data Sekunder OPMU, 2016)

Hasil wawancara dan observasi menunjukkan bahwa proses penerimaan dan penyelesaian laporan atau pengaduan itu kemudian didasari berdasarkan mekanisme dan prosedur yang ada pada Ombudsman, yakni mulai dari tahapan registrasi, seleksi, pemeriksaan secara substansi, tahapan klarifikasi, mediasi sampai pada pemanggilan dan rekomendasi. Ombudsman Maluku Utara sebagai sebuah lembaga yang berperan menangani persoalan maladministrasi yang dilakukan oleh aparat pelayanan publik tentunya telah memiliki standar Operasional Prosedur (SOP), sebab setiap laporan yang diterima maupun yang diselesaikan harus mengacu pada SOP yang berlaku secara baku atau bersifat tetap. Standar Operasional Prosedur (SOP) Ombudsman MU selanjutnya menjadi landasan kinerja bagi setiap personil termasuk dalam melakukan tindakan penanganan kasus yang dilaporkan oleh masyarakat. Hal tersebut dapat dipertegas oleh AI asisten Ombudsman yang menyatakan bahwa:

"Setiap laporan yang kami terima maupun yang akan kami selesaikan itu sesuai dengan mekanisme yang tentunya tidak lepas dari pada Standar Operasional Prosedur (SOP) yang berlaku di Ombudsman, dan telah menjadi sandaran baku bagi Ombudsman dalam menjalankan fungsi, tugas, dan wewenangnya (Hasil wawancara AI, Juni 2016)”. 


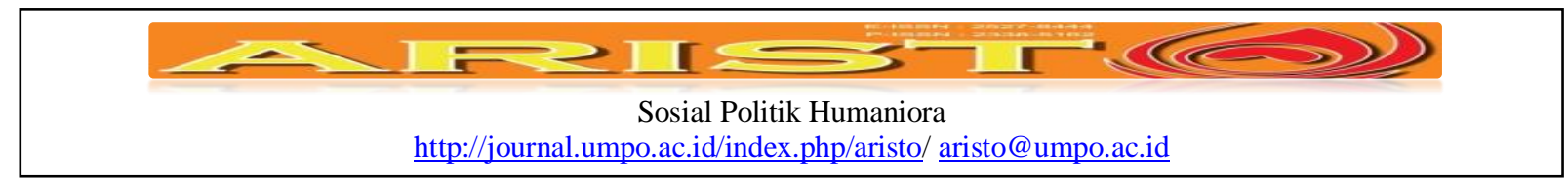

Dari uraian diatas mempertegas bahwa setiap jenis dan tahapan laporan yang disampaikan oleh pihak pelapor kepada Ombudsman, telah memiliki standar yang baku, sehingga sangat sedikit kemungkinan untuk terjadi kelambatan dan kesalahan dalam penanganan perkara yang dilaporkan ke Ombudsman secara administrasi, kemudian pernyataan yang diperkuat adanya Standar Operasional Prosedur (SOP) bahwa setiap menerima laporan maupun laporan yang diselesaikan Ombudsman memiliki standar baku yang telah ditetapkan. Pernyataan ini sebagaimana diperkuat oleh Komisioner SA yang dalam hasil wawancaranya mengatakan bahwa:

"Di Lembaga Ombudsman ini tentunya juga memiliki Standar Operasional Prosedur (SOP), dimana kami dalam melakukan kinerja baik dalam penerimaan laporan maupun tahapan penyelesaian laporan pun berdasarkan SOP yang ada, apalagi Ombudsman ini adalah lembaga independen pengawasan pelayanan publik terhadap maladministrasi, sehingga kami harus memberikan contoh teladan pelayanan publik yang baik kepada masyarakat (Hasil wawancara SA, Juni 2016)”.

Hasil wawancara ini juga kemudian diperkuat oleh Yayan (2013) bahwa standar operasional prosedur (SOP) adalah serangkaian instruksi tertulis yang dibakukan mengenai berbagai proses penyelenggaraan aktivitas organisasi, bagaimana dan kapan harus dilakukan, di mana dan oleh siapa dilakukan. Ombudsman perwakilan Maluku Utara senantiasa bekerja sesuai dengan Standar Operasional Prosedur (SOP) yang dimiliki. Hal ini dapat pula dimaknai bahwa setiap lembaga apapun itu baik sektor pemerintah maupun swasta harus memiliki Standar Operasional Prosedur (SOP) yang tetap. Ombudsman perwakilan Maluku Utara sebagai lembaga pengawasan pelayanan publik memiliki ciri khas tersendiri yang dapat membedakan dengan lembaga lain, ciri khas tersendiri yang dimaksud adalah Ombudsman diberi fungsi, tugas dan kewenangan secara konstitusi untuk memberantas yang namanya maladministrasi yang dilakukan oleh penyelenggara pelayanan publik sampai dengan tahapan rekomendasi, ini yang dapat membedakan sehingga Ombudsman juga dituntut bekerja secara profesional, produktif, responsif dan responsibilitas dengan mengedepankan prinsip-prinsip administrasi dan prosedur yang berlaku (SOP).

\section{Kesimpulan}

Kinerja Ombudsam Perwakilan Maluku Utara (OPMU) dalam mewujudkan pelayanan yang prima di Kota Ternate cukup baik dengan melihat pada produktivitas Ombudsman dalam menjalankan fungsi pengawasannya, yakni mulai dari (a) kuantitas kerja Ombudsman meliputi: 


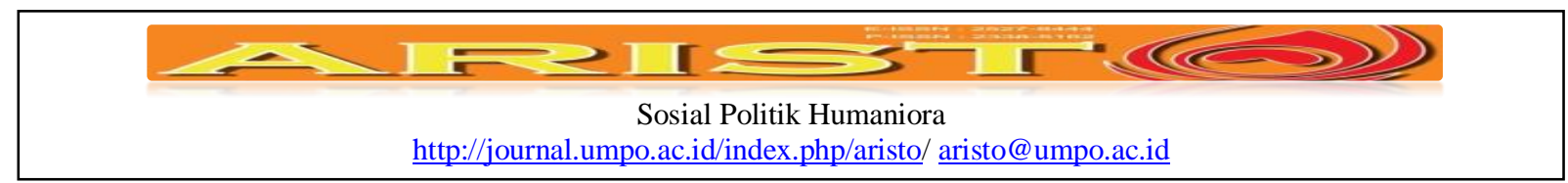

Proses dan Tahapan Penerimaan Laporan, melakukan Klarifikasi laporan, Infestigasi lapnagan, serta mediasi dan Rekomendasi (b) Kualitas Kerja meliputi: jumlah pengaduan masyarakat Kota Ternate yang masuk pada Ombudsman berjumlah berkisar 81 laporan suda termasuk swasta dan pemerintah, kemudian penyapaian laporan dari masyarakat yang cukup baik karena sesuai dengan mekanisme, melakukan proses tindaklanjuti laporan yang masuk dalam kewenangnan Ombudsman, (c) ketetapan waktu dalam penyelesaian laporan masyarakat.

Kinerja Ombudsman Perwakilan Maluku Utara khususnya di Kota Ternate cukup baik dengan melihat pada responsivitas Ombudsman terhadap aduan masyarakat meliputi: (a) sikap Ombudsman dalam merespon keluhan/laporan masyarakat Kota Ternate, (b) ombudsman melakukan perbaikan penyelenggara layanan dengan sosialisasi ke instansi penyelenggara layanan publik baik pemerintah maupun swasta, melakukan Focus Group Discusiion (FGD), seminar, Talk show melalui media, ombudsman juga bekoordinasi dan kerja sama dengan Stakeholder sebagai upaya terhadap pencegahan maladministrasi oleh pemerintah Kota Ternate. Selanjutnya dapat dilihat pada responsibilitas Ombudsman perwakilan Maluku Utara dalam penerimaan dan penyelesaian laporan dengan meliputi: kelengkapan administrasi/registrasi yang disiapkan ombudsman, kemudian pemeriksaan administrasi dan substantif laporan masyarakat , serta Standar Operasional Prosedur (SOP) yang diterapkan dan berlaku berlaku pada Ombudsman. 


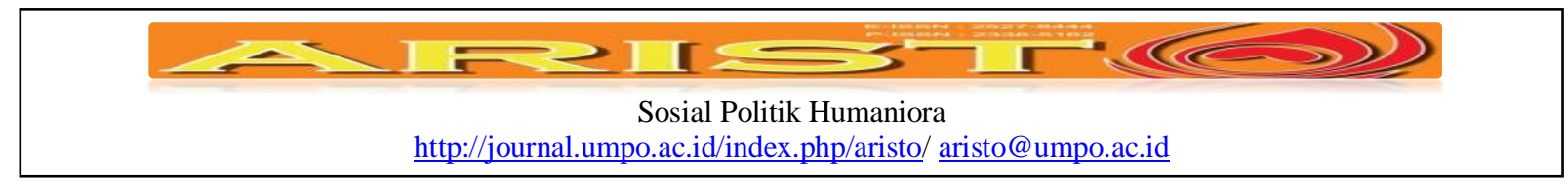

\section{Daftar Pustaka}

Andari, Switi, 2012. Pelaksanaan Fungsi Lembaga Ombudsman Daerah Yogyakarta dalam Rangka Mewujudkan GoodGovernance, Yogyakarta :Tesis Megister Hukum UGM.

Dwiyanto, Agus, 2006. Mewujudkan Good Governance Melayani Publik, Yogyakarta : Gadjah Mada University.

Hardiyansyah, 2015. Komunikasi Pelayanan Publik Konsep dan Aplikasi, Yogyakarta: Gava Media.

Mahsyar, A. (2011). Masalah Pelayanan Publik di Indonesia dalam Perspektif Administrasi Publik. Otoritas: Jurnal Ilmu Pemerintahan, 1(2).

Nadzaria, Yessy, 2013. Pelayanan Prima,Pengertian Pelayanan Prima dan dasar-dasar Pelayanan Prima $\quad \underline{\text { http://yessy- }}$ nadzariafib13.web.unair.ac.id/artikel detail94777Psikologi\%20Prinsip\%20Pelayanan\% 20Prima:\%20Pengertian\%20Pelayanan\%20Prima\%20dan\%20DasarDasar\%20Pelayana n\%20Prima.html, diakses pada tanggal 25 Oktober.

Pattarai, Idris, 2010. Ombudsman dan Akuntabilitas Publik: Kasus Daerah Istimewa Yogyakarata, Jakarta: CV. Jengki Satria.

Pramusinto, Agus, 2009: Reformasi Birokrasi, Kepemimpinan dan Pelayanan Publik: Kajian Tentang Pelaksanaan Otonomi Daerah di Indonesia, Yogyakarta: Gava Media.

Sembiring, Masna, 2012. Budaya dan Kinerja Organisasi (Prespektif Organisasi Pemerintah), Bandung: Fokusmedia

Simamora, Hendry, 2004. Manajemen Sumber Daya Manusia, Yogyakarta: STIE YKPN.

Syamsuddin, Aziz, 2009. Ombudsman Republik Indonesia: Merengkuh Keluhan Rakyat, Menjewer Sang Pejabat, Jakarta: Sinar Grafika.

Thoha, Mifta, 2003. Prilaku Birokrasi Dalam Pelayanan Publik, Jakarta: Pustaka Pelajar.

Uar, A. (2016). Pengaruh Pelaksanaan Prinsip-PrinsipGoodGovernance Terhadap Kinerja Pelayanan Publik Pada Badan Pertahanan Nasional (BPN) Kota Ambon. Otoritas: Jurnal Ilmu Pemerintahan, 6(1), 1-11. 


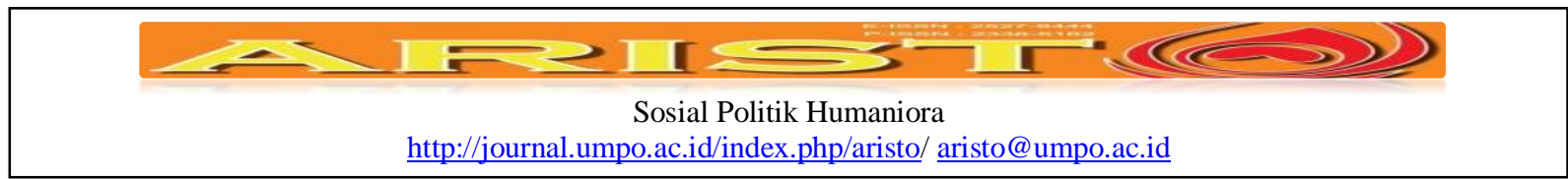

Usman, J. (2011). Manajemen Birokrasi Profesional dalam Meningkatkan Pelayanan Publik. Otoritas: Jurnal Ilmu Pemerintahan, 1(2).

Yayan, 2013 . Memahami Konsep dasar Pelayanan Publik http://yayan-sfisip.web.unair.ac.id/artikel detail70823komsosbang Memahami\%20Konsep\%20Dasar\%20Pelayanan\%20Publik.html, diakses pada tanggal 21 Oktober

Undang-Undang No. 37 Tahun 2008 tentang Ombudsman Republik Indonesia.

Undang-Undang No. 25 Tahun 2009 tentang Pelayanan Publik. 